\title{
Effect of Neodymium: Yttrium-Aluminium-Garnet Laser Capsulotomy on Endothelial Cells Count in Posterior Capsular Opacification
}

\section{Qasim KF1* and Hasanain $\mathrm{AR}^{2}$}

${ }^{1}$ Department of Ophthalmology, College of Medicine, University of Babylon, Iraq 2Ibn Al Haitham Teaching Eye Hospital, Iraq

*Corresponding author: Qasim K Farhood, Department of Ophthalmology, College of Medicine, University of Babylon, Babylon, 52001, Iraq, Tel: +964 7801179098 ; Email: qasim_1964@ymail.com

\section{Research Article}

Volume 3 Issue 6

Received Date: October 30, 2018

Published Date: December 13, 2018

DOI: $10.23880 /$ oajo-16000169

\section{Abstract}

Aim: to determine the effect of ND-YAG laser posterior capsulotomies on endothelial cells count in patients attending Ibn Al Haitham teaching eye hospital.

Patients and Methods: It is a Prospective non-comparative case series study including patients with clinically significant posterior capsular opacification (PCO) attended Ibn Al Haitham teaching eye hospital from June 2016 to February 2017. Detailed history taking and complete ophthalmic examinations done for all patients, Corneal endothelial cells count was done by using non-contact specular microscopy (topcon sp 3000) before YAG laser, 1 week and 4 weeks after laser to determine the endothelial cells count. Data were analyzed by using ANOVA, F test and paired $\mathrm{t}-\mathrm{test}$.

Results: Sixty-five eyes of 65 patients presented with clinically significant PCO were included, 40 patients where males $(61.5 \%)$ and 25 patients females (38.5\%). The mean of endothelial cells count before laser was $\left(2047 \mathrm{cell}^{2} \mathrm{~mm}^{2}\right), 1 \mathrm{week}$ after laser (1938 cell $/ \mathrm{mm}^{2}$ ) and 4 weeks after laser (1916 cell/ $\mathrm{mm}^{2}$ ), the difference between pre-laser endothelial cells count and 1-4 wks after laser was (109 cell), (131 cell) respectively which is found to be significant (p value 0.04 ).

Conclusion: In our study, posterior capsule opacification when treated with ND-YAG laser is associated with statistically significant reduction in the endothelial cells count. The yag laser posterior capsulotomy is noninvasive and effective modality of treatment of PCO but the corneal endothelial cells may be damaged by laser.

Keywords: Neodymium: Yttrium-Aluminum-Garnet; Laser Capsulotomy; Posterior Capsule Opacity; Endothelial Cells Count

Abbreviations: PCO: Posterior Capsular Opacification; IOP: Intraocular Pressure; SPSS: Statistical Package For
Social Sciences. 


\section{Introduction}

\section{Posterior Capsular Opacification}

Following uncomplicated cataract surgery posterior capsular opacification (PCO) is most common late complication. PCO causes decrease of visual acuity, decrease contrast sensitivity and may cause monocular diplopia or glare. The incidence of PCO is reduced when the opening of continuous curvilinear capsulorrhexis is in complete contact with IOL anterior surface. Lens type that are more prone for posterior capsular opacification are PMMA and probably to a lesser extent hydrogel IOLs, but the design of IOL is more important than material; notably, a square edge of the optic appears to inhibit PCO [1].

PCO is a major problem after cataract surgery in pediatric age group where the incidence reaches $100 \%$ between 2 months and 5 years after the initial surgery. The incidence of PCO is range from less than $5 \%$ to $50 \%$ in eyes undergoing uneventful cataract surgery for senile cataracts [2].

\section{Risk Factors}

Several systemic and ocular associations have been associated with the development of PCO [3]. The risk factors for PCO have revealed no association between PCO and gender, age, or axial length of the eye. Diabetic patients after cataract surgery had significant PCO when compared with non-diabetics after 1 year follow up. However, the degree of PCO did not seem to correlate with the severity of diabetic retinopathy and the systemic condition of diabetics [4]. Myopic eyes found to be at risk for an increased PCO probably because IOL implantation was deferred in them [5]. However study of Hayashi, et al. concluded that with IOL implantation in myopic eyes, there is no correlation between degree of myopia and degrees of PCO. The uveitis is found to be a risk factor for increased incidence of PCO [6]. In these eyes, hydrophobic acrylic IOLs found to lower the incidence of PCO and provide a better visual outcome than PMMA, silicone or heparin-surface-modified PMMA IOLs [7]. Patients with myotonic dystrophy developed thick PCO following cataract surgery which required multiple capsulotomies [8]. Also higher incidence of PCO occurs in patients with retinitis pigmentosa and it is significantly higher in traumatic cataracts, it has been quoted to be as high as 92 $\%$ at the three-year follow-up $[9,10]$.

\section{Histologic Examination}

Histology of PCO is characterized by residual lens epithelial cells undergo reaction of tissue repair after cataract surgery and IOL implantation, lens epithelial cells transform to lens fibers and myofibroblasts, this lead to Soemmering ring development in periphery of capsular bag and Elschnig pearl on inner surface of posterior capsule [11]. Histology showed presence of lens like cellular arrangement called epithelial mesenchymal transition (EMT) and lead to fibrous tissue on capsule [12].

\section{Treatment}

1. Nd: YAG laser to create an opening in posterior capsule [1].

2. Surgical treatment with a discussion knife, vitrectomy hand piece, or scissors in dense fibrosis in which laser treatment insufficient [13]. The neodymium yttrium aluminum garnet ( $\mathrm{Nd}$ : $\mathrm{YAG}$ ) laser: is a solid type of laser, its work by causes disruption of tissue by ionization mode of action or photo-disruption. It has a wavelength of 1064 nanometers in the infrared range of radiation. It is commonly used to disrupt the posterior capsule opacity following cataract surgery [14].

\section{Specular Microscopy}

Is a non-invasive technique to assess the corneal endothelium both structure and function. There are multiple specular microscope companies, each capturing the cell images at different magnifications and calibrations. The clinical specular microscopes are all based on the laboratory microscope designed by Maurice, to provide a high magnification view of specular reflected light from the corneal endothelium. The endothelial cells can be imaged because the refractive index of the endothelial cells is greater than the 1.336 value for aqueous humor, thus reflecting $0.022 \%$ of the projected light [15].

Specular microscopy use computer-assisted software, modern specular microscopes can analyze the shape, size and population of the endothelial cells. It uses light that projects onto the cornea and captures the image reflected from the optical interface between corneal endothelium and the aqueous humor. The reflected image is analyzed by the instrument and displayed as a specular photomicrograph [16].

The corneal endothelium is a single layer of polygonal cells that firmly attached to the Descemet's membrane and is in contact with the aqueous humor, it is believed to be originated from neural crest. Control the hydration state of the corneal stroma through an active pumping is 


\section{Open Access Journal of Ophthalmology}

the main function of corneal endothelium, thereby providing transparency of the cornea. Damage to the endothelium is more potentially serious than that of damage to other corneal layers [17].

The normal surface area of human corneal endothelium is approximately $130 \mathrm{~mm}^{2}$ [18]. The normal cell density of children 3-6 years old was approximately 4000 to 3500 cells per $\mathrm{mm}^{2}$. This value decreases with age and the surface area of cornea increases. Middle adults (30 years of age) a range of cells count between 2700 to 2900 cells per $\mathrm{mm}^{2}$, and $>75$ years old can have a range of cell densities between 2400 to 2600 cells per $\mathrm{mm}^{2}$. The Asian race has more cell densities than other races per given age group [15].

\section{Patients and Methods}

Prospective non comparative case study including 65 eyes of 65 patients (40 males and 25 females) age between $47-72$ years with mean $(58.8 \pm 6.4)$ presented with clinically significant posterior capsular opacification attended Ibn Al Haitham teaching eye hospital from June 2016 to February 2017. Detailed history taking from the patients and complete ophthalmic examination done, phacoemulsification was done for all patients included in the study. Time interval between cataract surgery and $\mathrm{Nd}$ : YAG laser posterior capsulotomy was 1-3 years.

\section{Exclusion Criteria:}

1. Patients with corneal pathology like endothelial dystrophy, scar or trauma.

2. Retinal pathology.

3. Pseudoexfoliation syndrome.

4. Active uveitis.

5. Traumatic cataract.

6. Primary or secondary glaucoma.

7. Diabetes mellitus

The following protocols were done before YAG laser capsulotomy which include, measuring of uncorrected and best corrected visual acuity, measurement of intraocular pressure (IOP), slit-lamp examination, dilated fundus examination and specular microscopy using noncontact SP-3000 P (Topcon) version. The method of fixation that used is central fixation to capture the center area of cornea (auto alignment). Area of the cornea that examined $8 \mathrm{~mm} \times 8 \mathrm{~mm}$ in which focusing and centering was automatically done. The image then transferred to the computer, which provided highly precise analysis of the endothelium. $1 \%$ tropicamide eye drops were instilled to dilate the pupil and the cornea was anaesthetized with topical $0.5 \%$ tetracaine hydrochloride eye drops. Then
YAG laser capsulotomy using Q-switched protocol was applied.

Topical steroid (dexamethasone eye drop qid) and (timolol $0.5 \%$ ) eye drop bid for 1 week were prescribed for all patients after YAG laser capsulotomy. Ocular examination was done after 1 week including visual acuity, presence of uveitis, rise in IOP, vitritis, cystoid macular edema and retinal detachment.

\section{Statistical Analysis}

Data of the 65 patients were analyzed using the statistical package for social sciences (SPSS) version 24. Descriptive statistics presented as mean, standard deviation (SD), frequencies and proportions. Chi square test was used to compare frequencies, Analysis of variances (ANOVA test) was used to compare means, paired t test was used to compare two means (pre-laser versus one week or one month post laser) Level of significance, $P$ value $\leq 0.05$ considered as significant.

Ethical Issue: the Scientific Council of Ophthalmology of Iraqi Board for Medical Specializations approved this study. The research followed the tenets of the Declaration of Helsinki, and each patient gave his or her written informed consent to participate in the study.

\section{Results}

65 eyes of 65 patients presented with clinically significant PCO were included in this study, 40 patients where males (61.5\%) and 25 patients females (38.5\%). Age of patients range (47-72) years with the mean 58.8 (SD 6.4). (Table 1) Mean of endothelial cells count before laser (2047 cell $/ \mathrm{mm}^{2}$ ), $1 \mathrm{wk}$ after laser (1938 cell/ $\mathrm{mm}^{2}$ ) and $4 \mathrm{wk}$ after laser (1916 cell/ $\mathrm{mm}^{2}$ ) ,the difference between pre-laser endothelial cell count and 1-4 wks after laser was (109 cell), (131 cell) respectively which is found to be highly significant $p$ value 0.04 (Table 4).

\begin{tabular}{|c|c|c|c|}
\hline \multicolumn{2}{|c|}{ Variable } & No. & \% \\
\hline \multirow{4}{*}{ Age (year) } & $\leq 50$ & 11 & 16.9 \\
\cline { 2 - 4 } & $51-60$ & 22 & 33.8 \\
\cline { 2 - 4 } & $>60$ & 32 & 49.2 \\
\hline \multirow{3}{*}{ Gender } & Mean $\pm S D^{*}$ & $58.8 \pm 6.4$ & - \\
\hline & Male & 40 & 61.5 \\
\cline { 2 - 4 } & Female & 25 & 38.5 \\
\hline \multicolumn{3}{|c|}{${ }^{*} S D:$ Standard deviation } \\
\hline
\end{tabular}

Table 1: Age and gender distribution of the studied group $(\mathrm{N}=65)$. 


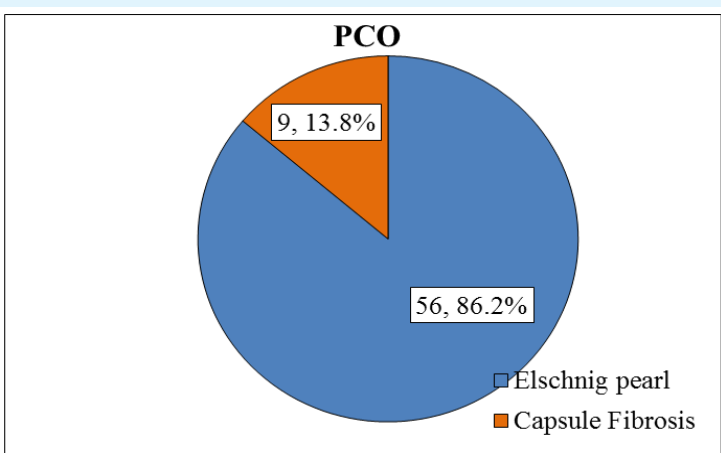

Figure 1: Distribution of the studied group according to PCO.

Table 2 showed no significant difference in mean IOP at different time of follow up ( $\mathrm{P}>0.05)$.

\begin{tabular}{|c|c|c|}
\hline \multirow{2}{*}{} & \multicolumn{2}{|c|}{ Intraocular pressure } \\
\cline { 2 - 3 } & Mean & SD \\
\hline Pre-Laser & 14.8 & 1.7 \\
\hline One week & 15.2 & 1.7 \\
\hline One month & 15.1 & 1.5 \\
\hline \multicolumn{2}{|c|}{ ANOVA, F test , $\mathrm{P}=0.334$} \\
\hline
\end{tabular}

Table 2: Intraocular pressure of the studied group $(\mathrm{N}=$ $65)$.

Table 3, shows number of shots that were used ranged from $(7-21)$, the mean was 16 shots, while energy used range from $(27-157 \mathrm{~mJ})$, Mean $82 \mathrm{MJ}$.

\begin{tabular}{|c|c|c|c|}
\hline & Mean & SD & Range \\
\hline No. of shots & 16 & 3 & $7-21$ \\
\hline Total energy & 82 & 30 & $27-157$ \\
\hline \multicolumn{2}{|c|}{${ }^{*}$ SD : Standard deviation } \\
\hline
\end{tabular}

Table 3: Mean values of number of shots and total energy.

\begin{tabular}{|c|c|c|c|}
\hline & Mean & SD & Range \\
\hline Pre-Laser & 2047 & 369 & $1140-2710$ \\
\hline One week & 1938 & 380 & $1065-2680$ \\
\hline One month & 1916 & 379 & $1015-2650$ \\
\hline ANOVA, F test, $\mathrm{P}=0.04$, significant difference \\
Multiple comparison (paired t test) \\
\hline Pre-Laser compared to one month, significant \\
difference (reduction), (P = 0.025). \\
Pre-Laser compared to one week, no significant \\
difference (P>0.05) \\
One week compared to one month, no significant \\
difference (P>0.05)
\end{tabular}

Table 4: Endothelial cell count of the studied group at different follow up time $(\mathrm{N}=65)$.

Qasim KF and Hasanain AR. Effect of Neodymium: Yttrium-AluminiumGarnet Laser Capsulotomy on Endothelial Cells Count in Posterior Capsular Opacification. J Ophthalmol 2018, 3(6): 000169.

\begin{tabular}{|c|c|c|c|c|}
\hline \multirow{2}{*}{ Visual acuity } & \multicolumn{2}{|c|}{ Pre-Laser } & \multicolumn{2}{c|}{ One month } \\
\cline { 2 - 5 } & No. & \% & No. & \% \\
\hline $6 / 6$ & 1 & 1.5 & 14 & 21.5 \\
\hline $6 / 9$ & 3 & 4.6 & 18 & 27.7 \\
\hline $6 / 12$ & 18 & 27.7 & 20 & 30.8 \\
\hline $6 / 18$ & 21 & 32.3 & 5 & 7.7 \\
\hline $6 / 24$ & 7 & 10.8 & 6 & 9.2 \\
\hline $6 / 36$ & 13 & 20.0 & 2 & 3.1 \\
\hline $6 / 60$ & 2 & 3.1 & 0 & 0.0 \\
\hline \multicolumn{4}{|c|}{ Chi square was significant, $\mathrm{P}<0.001$} \\
\hline
\end{tabular}

Table 5: Distribution of visual acuity of the patients at baseline and at one month.

\section{Discussion}

Nowadays cataract surgery is common whether extracapsular cataract extraction or by phacoemulsification techniques used. PCO is a common complication after cataract surgery which may affect vision by decreasing visual acuity, decrease the field of view during diagnostic and therapeutic procedures, decrease the contrast sensitivity, because glare and may cause diplopia. Surgical capsulotomy was the only method for treatment of PCO before development of ND: YAG laser [2]. YAG laser capsulotomy nowadays is a common procedure, it is safe and non invasive to remove the PCO [19].

Hence in current study 65 patients presented with PCO where included, 9 patients had capsular fibrosis $(13.8 \%)$ and 56 patients had elschnig's type (86.2\%). we found that the mean of ECC pre-laser was (2047 cells $/ \mathrm{mm}^{2}$ ), one week after laser was 1938 cells $/ \mathrm{mm}^{2}$ and (1916 cells $/ \mathrm{mm}^{2}$ ) 4 weeks after laser, the differences between pre-laser, 1week and 4 weeks were (109) cells, (131) cells respectively, so the decrease in ECC is particularly highly significant between prelaser and 4wks after laser ( $P$ value $=0.025)$, although there is decrease in ECC between prelaser and $1 \mathrm{wk}$ post laser, but it is statistically insignificant $(\mathrm{P}$ value $=>0.05)$, this may be due to a late effect of YAG laser.

These findings are comparable with study reported by Rajappe, et al. who found that the mean of ECC pre-laser 2298 cells $/ \mathrm{mm}^{2}, 1 \mathrm{wk} 2178$ cells $/ \mathrm{mm}^{2}$ and 12 wks was 2121 cells $/ \mathrm{mm}^{2}$, the difference between pre and postlaser 1-12 weeks was highly significant ( $p$ value $\leq 0.001$ ) [2]. Similarly another study by Bazard, et al. which also found significant difference in ECC before and 3 months after laser $p$ value $<0.02[20]$. 


\section{Open Access Journal of Ophthalmology}

While D. Ruiz -casas, et al. studied the effect of yag laser on 31 pseudophakic eyes with PCO, found that YAG laser not affect the ECC significantly $\mathrm{p}$ value $=0.4$. study done by Slomovic, et al. which examined 39 eyes with PCO and evaluate effect of yag laser, the results showed the mean ECC before laser 1840 cells $/ \mathrm{mm}^{2}$ and after laser 1798 cells $/ \mathrm{mm}^{2}$ the difference between them 42 cells $2.3 \%$ cells loss, so concluded that there is no significant correlation between corneal endothelial cell loss and yag laser energy [21,22]. Also Kanchanaranya, et al. in their study included 41 patients with PCO found that mean of ECC pre laser 2213 cells $/ \mathrm{mm}^{2}, 1$ month post-laser 2177 cells $/ \mathrm{mm}^{2}$ and 3 months post-laser 2237 cells $/ \mathrm{mm}^{2}$, the difference of ECC between pre and post-laser at 1 and 3 months were statistically insignificant [19]. In last 3 studies the explanation of not concluding significant correlation between ECC and YAG laser may be due to small sample size [21].

This discrepancy between studies in endothelial cells loss may be due to ethenic variation, different sample size, technician endothelial cells measurement, nature of tissue being disrupted, differences in delivery of laser energy (number of pulses per burst, mode of delivery, quantity of energy) and target tissue endothelial distance.

Regarding the IOP, in our study there is mild relative increase in mean IOP from $14.8 \mathrm{mmHg}$ prelaser to $15.2 \mathrm{mmHg}, 15.1 \mathrm{mmHg}$ post laser 1 week and 4 weeks respectively, which is statistically not significant elevation ( $p$ value $=0.33$ ), also Rajappe, et al. found no any elevation in IOP after YAG laser even after follow up period of 12 weeks [2]. Also Shani, et al. found no any elevation in IOP after YAG laser [23]. While in other studies, slomovic and parrish, et al. they mentioned there is significant increase in IOP following YAG laser in $55 \%$ of their patients [24]. This discrepancy between different studies regarding IOP may be due to use of timolol eye drop bid for 1 week after YAG laser in both studies and the use of dexamethasone eye drop for 1 week, number of pulses applied, pulse energy and total energy of YAG laser.

\section{Conclusion and Recommendation}

PCO is a common complication after cataract surgery, as Nd: YAG laser capsulatomy is safe, effective and noninvasive method of treatment of PCO, it may cause corneal endothelial cells damage. To decrease damage of the endothelial cells during YAG laser posterior capsulotomy:

1. Accurate focusing on posterior capsule

2. Use of lowest energy setting

3. Stabilization of the eye by contact lens in uncooperative patient

\section{References}

1. Bowling B, Kanski JJ (2015) Kanski's clinical ophthalmology: a systemic approach. $8^{\text {th }}$ (Edn.), Edinburgh: Elsevier, pp: 293.

2. Rajappa N, Lune A, Radhakrishnan OK, Magdum R, Patil P, et al. (2013) Evaluation of corneal endothelium before and after neodymium: Yttriumaluminium-garnet laser capsulotomy in posterior capsular opacification. Sudanese Journal of Ophthalmology 5(2): 73.

3. Raj SM, Vasavada AR, Johar SR, Vasavada VA, Vasavada VA (2007) Post-operative capsular opacification: a review. Int J Biomed Sci 3(4): 237250.

4. Ebihara Y, Kato S, Oshika T, Yoshizaki M, Sugita G (2006) Posterior capsule opacification after cataract surgery in patients with diabetes mellitus. J Cataract \& Refract Surg 32(7): 1184-1187.

5. Hayashi K, Hayashi H, Nakao F, Hayashi F (2002) Posterior capsule opacification after cataract surgery in patients with diabetes mellitus. Am J Ophthalmol 134(1): 10-16.

6. Hayashi K, Yoshida M, Hayashi H (2006) Posterior capsule opacification in myopic eyes. J Cataract Refract Surg 32(4): 634-638.

7. Rahman I, Jones NP (2005) Long-term results of cataract extraction with intraocular lens implantation in patients with uveitis. Eye 19(2): 191-197.

8. Alió JL, Chipont E, BenEzra D, Fakhry MA, Group IO (2002) Comparative performance of intraocular lenses in eyes with cataract and uveitis. J Cataract \& Refract Surg 28(12): 2096-2108.

9. Garrott HM, Walland MJ, O'Day J (2004) Recurrent posterior capsular opaci Capsular opacification fication and capsulorhexis contracture after cataract surgery in myotonic dystrophy. Clin Exp Ophthalmol 32(6): 653-655.

10. Auffarth GU, Nimsgern C, Tetz MR, Krastel H, Völcker HE (1997) Increased cataract rate and characteristics of Nd: YAG laser capsulotomy in retinitis pigmentosa. Ophthalmologe 94(11): 791-795. 


\section{Open Access Journal of Ophthalmology}

11. Krishnamachary M, Rathi V, Gupta S (1997) Management of traumatic cataract in children. J Cataract Refract Surg. 23(1): 681-687.

12. Miyamoto T, Ishikawa N, Shirai K, Kitano-Izutani A, Tanaka SI, et al. (2014) Histology of Posterior Capsular Opacification. Lens Epithelium and Posterior Capsular Opacification pp: 177-188.

13. Bobrow JC (2015-2016) Complications of Cataract Surgery. In: Basic and Clinical Science Course (BCSC) Section 11: Lens and Cataract. San Francisco, CA: Amer Academy of Ophthalmology, pp: 170-173.

14. Aslam TM, Devlin H, Dhillon B (2003) Use of Nd: YAG laser capsulotomy. Surv Ophthalmol 48(6): 594-612.

15. McCarey BE, Edelhauser HF, Lynn MJ (2008) Review of corneal endothelial specular microscopy for FDA clinical trials of refractive procedures, surgical devices and new intraocular drugs and solutions. Cornea 27(1): 1-16.

16. Craig T (2009) Use specular microscopy to diagnose corneal disease. Review of Optometry 146(6).

17. Mimura T, Yokoo S, Yamagami S (2012) Tissue engineering of corneal endothelium. J Funct Biomater 3(4): 726-744.

18. Zavala J, Jaime GL, Barrientos CR, Valdez-Garcia J (2013) Corneal endothelium: developmental strategies for regeneration. Eye 27(5): 579-588.
19. Kanchanaranya N, Sonthirathi S (2015) Effect of Neodymium: YAG (ND: YAG) Laser Capsulotomy on the Corneal Endothelium in Treating Posterior Capsule Opacity. Thammasat Thai Journal of Ophthalmology 7(2): 6-12.

20. Bazard MC, Guldenfels Y, Raspiller A (1988) Early endothelial complications after treatment using a neodymium-Yag laser. J Fr Ophtalmol 12(1): 17-23.

21. Ruiz-Casas D, Barrancos C, Alio JL, Ruiz-Guerrero M, Munoz-Negrete FJ (2013) Effect of posterior neodymium: YAG capsulotomy. Safety evaluation of macular foveal thickness, intraocular pressure and endothelial cell loss in pseudophakic patients with posterior capsule opacification. Arch Soc Esp Oftalmol 88(11): 415-422.

22. Slomovic AR, Parrish RK, Forster RK, Cubillas A (1986) Neodymium-YAG laser posterior capsulotomy: central corneal endothelial cell density. Arch Ophthalmol 104(4): 536-538.

23. Shani L, David R, Tessler Z, Rosen S, Schneck M, et al. (1994) Intraocular pressure after neodymium: YAG laser treatments in the anterior segment. J Cataract Refract Surg 20(4): 455-458.

24. Slomovic AR, Parrish RK (1985) Acute elevations of intraocular pressure following $\mathrm{Nd}$ : YAG laser posterior capsulotomy. Ophthalmology 92(7): 973976. 